\title{
EVAPORATION PAN AS AN EFFECTIVE METHOD FOR IRRIGATION SCHEDULING FOR SUGAR BEET IN THE NORTH NILE DELTA REGION \\ El-Hadidi, E. M. ${ }^{1}$; M. M. Ibrahim ${ }^{2}$ and Mona S. M. Eid ${ }^{3}$ \\ 1- Soils Dept., Fac. of Agric. Mansoura Univ. \\ 2- Soil and Water Dept., Fac. of Agric. Tanta Univ. \\ 3- Soils, Water and Environment Res. Institute, A.R.C., Giza.
}

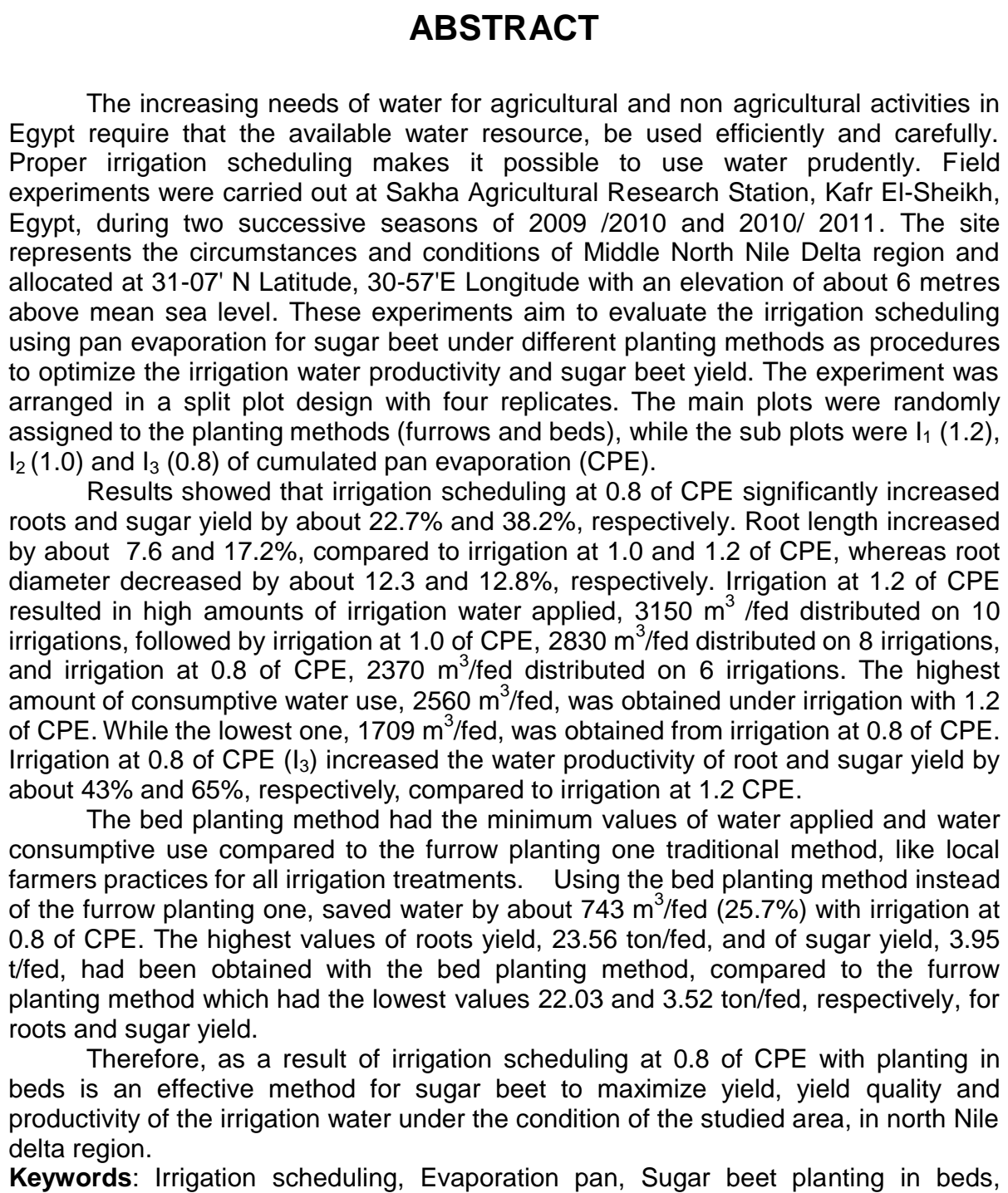
water productivity. 


\section{INTRODUCTION}

Like many countries of the world, water resources of Egypt are diminishing quantitatively and qualitatively. Egypt is the solely country in the world that its agricultural production repents depends upon irrigation; i.e.no rain fed agriculture from the economic point of view is practiced due to the very dry condition with mean annual rainfall of less than $250 \mathrm{~mm}$. Agriculture is the main sector in water consumption with more than $85 \%$ from total national water supply However, water productivity (WP) is very low. The main reason for low productivity is the over irrigation by the farmers. Farmers normally over irrigate the fields due to lack of proper knowledge about irrigation scheduling; and with the intention that more water will produce more yield. However, more applications of water may result in low WP and low net income. (Ashraf et al., 2001).

Irrigation scheduling is the decision of when and how much water to apply to a field. Its purpose is to maximize irrigation efficiencies by applying the exact amount of water needed to replenish the soil moisture to the desired level. It saves water and energy, (Jensen 1980). It has been described as the primary tool to improve water use efficiency, increase crop yields, increase the availability of water resources, and provoke a positive effect on the quality of soil and groundwater, (FAO, 1996).

The increasing needs of water for agricultural and nonagricultural activities require that the available water resources, for both surface and groundwater be used efficiently and carefully. Proper irrigation scheduling makes it possible to use water prudently. The technique of using pan evaporation for irrigation scheduling has been extensively tested by many researchers in Egypt (Khalil, 1996; Ashraf et al., 2002; Khalil et al., 2006) and it was proven to save up to $20 \%$ of the applied irrigation water by farmers. Therefore, under Egyptian conditions, extension agricultural is recommending scheduling irrigation using pan evaporation technique to the farmers as a way to conserve irrigation water. In spite of the difficult for a common farmer to maintain and to read exact level in the pan, evaporation pan can be attached with a farm to make it simple for a common farmer to design irrigation scheduling.

One of the main national strategies in agriculture is cultivating sugar beet instead of sugar cane the highest water need crop. To produce one ton of sugar from beet, it needs almost one quarter of water in comparison to that for sugar cane, (Doorenbos et al.1979). The traditional planting method for sugar beet at Kafr El-Sheikh Governorate, the main area in national sugar beet production, is planting in furrows. The spacing of furrows is influenced by the soil type and the cultivation practice. On clay soils, the spacing between two adjacent furrows should be $75-150 \mathrm{~cm}$. On clay soils, doubleridged furrows, sometimes called beds, can also be used. Their advantage is that more plant rows are possible on each ridge, facilitating manual weeding. The ridge can be slightly rounded at the top to drain off water that would otherwise tend to pond on the ridge surface during heavy rainfall, (Wang et al. 1999). The method of planting in beds which tested on some field and 
vegetable crops were effective in increasing the crop yield and the water use efficiency. (Anonymous, 2006) reported that the maximum water saving and highest seed cotton yield was produced by the bed (raised bed) planting method. (Raut et al. 2000) found that soybean seed yield with 2 rows per bed higher than with 1 row per bed, although there were more pods per plant with 1 row per bed. So far, sugar beet planting in beds not yet tested.

Therefore, the aim of the present investigation was to study the impact of the irrigation scheduling using pan evaporation under two planting methods, furrows and beds, on sugar beet yield and on the irrigation water productivity to introduce the most suitable planting method and water treatment to optimize water use and sugar beet yield.

\section{MATERIALS AND METHODS}

\section{Experimental site}

A field trial was conducted during the two successive growing seasons 2009/2010 and 2010/2011 at Sakha Agricultural Research Station, Kafr ELShiekh, Egypt. The site represents the circumstances and conditions of Middle North Nile Delta region and allocated at 31-07' N Latitude, 30-57'E Longitude with an elevation of about 6 meters above mean sea level. Agro meteorological data of Sakha station, during the two growing seasons of study are presented in Table (1). The soil of the experimental site was clayey in texture. The average of electrical conductivity of soil salinity, in soil paste extract, over $0-60 \mathrm{~cm}$ depth was $3.76 \mathrm{dSm}^{-1}$. Some soil physical properties of the experimental site are presented in Table (2).

Table (1): Mean of some meteorological data for Kafr El-Sheikh area during the two growing seasons of sugar beet crop.

\begin{tabular}{|c|c|c|c|c|c|c|c|c|c|c|c|c|c|c|}
\hline \multirow{3}{*}{ 들 } & \multicolumn{7}{|c|}{ Season $2009 / 2010$} & \multicolumn{7}{|c|}{ Season 2010/2011 } \\
\hline & \multicolumn{2}{|c|}{ 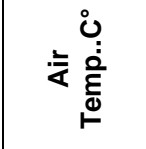 } & \multicolumn{2}{|c|}{ 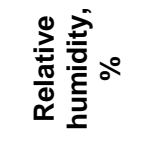 } & \multirow{2}{*}{ 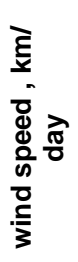 } & \multirow{2}{*}{$\begin{array}{l}\frac{\vec{\sigma}}{0} \\
\text { ह } \\
\text { E } \\
\text { 요 }\end{array}$} & \multirow{2}{*}{ 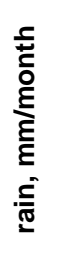 } & \multicolumn{2}{|c|}{ 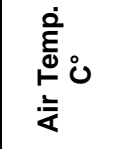 } & \multicolumn{2}{|c|}{ 竞章 } & \multirow{2}{*}{$\begin{array}{c}\text { wind } \\
\text { speed } \\
\text {, km/ } \\
\text { day }\end{array}$} & \multirow{2}{*}{$\begin{array}{l}\text { Ep, } \\
\mathrm{mm} / \\
\text { day }\end{array}$} & \multirow{2}{*}{ 돈 $\frac{\text { 들 }}{\frac{E}{E}}$} \\
\hline & maxi. & $\min$. & $\max$ & $\min$ & & & & $\max$ & $\min$ & $\max$ & $\min$ & & & \\
\hline Nov. & 26.0 & 10.5 & 77.7 & 50.0 & 58 & 2.7 & 0.0 & 26.8 & 11.0 & 82.0 & 54.2 & 63 & 2.8 & ------ \\
\hline Dec. & 22.2 & 8.8 & 76.5 & 52.0 & 64.0 & 2.1 & 5,8 & 22.0 & 8.3 & 85.0 & 55.7 & 58.3 & 1.8 & 90.0 \\
\hline Jan. & 21.5 & 7.8 & 83.5 & 55.0 & 53.0 & 1.8 & 0.0 & 20.3 & 5.8 & 84.2 & 54.0 & 42.5 & 1.9 & ------- \\
\hline Feb. & 24.5 & 9.4 & 84.2 & 55.7 & 76.8 & 2.9 & 32 & 23.4 & 7.4 & 87.0 & 54.0 & 64.0 & 2.9 & 22.5 \\
\hline Mar- & 24.3 & 10.0 & 76.3 & 44.0 & 110 & 4.3 & 0.0 & 21.8 & 6.8 & 86.3 & 49.5 & 77.4 & 3.4 & 14.0 \\
\hline Apr- & 28.2 & 11.0 & 96.0 & 40.7 & 96 & 5.6 & 0.0 & 26.5 & 10.0 & 85.0 & 47.7 & 83.7 & 4.9 & ---- \\
\hline May- & 29.6 & 14.4 & 72.6 & 39.5 & 96 & 6.9 & 0.0 & 29.0 & 13.0 & 76.7 & 38.0 & 102.0 & 5.9 & ----- \\
\hline
\end{tabular}
$6 \mathrm{~m}$. 
El-Hadidi, E. M. et al.

Table (2): Some soil physical analysis for the experimental site.

\begin{tabular}{|c|c|c|c|c|c|c|c|c|c|}
\hline \multirow[t]{2}{*}{ Depth } & \multicolumn{3}{|c|}{ Particle size distribution } & \multirow[t]{2}{*}{ Texture } & \multirow{2}{*}{$\begin{array}{l}\text { F.C } \\
\text { W\% }\end{array}$} & \multirow{2}{*}{$\begin{array}{l}\text { PWP } \\
\text { W\% }\end{array}$} & \multirow{2}{*}{$\begin{array}{l}\text { Bulk } \\
\text { density } \\
\mathrm{Mg} / \mathrm{m}^{3}\end{array}$} & \multicolumn{2}{|c|}{$\begin{array}{c}\text { Available } \\
\text { water }\end{array}$} \\
\hline & Sand \% & Silt \% & Clay \% & & & & & w\% & $\mathbf{m m}$ \\
\hline $0-15$ & 15.28 & 18.80 & 65.92 & Clayey & 47.2 & 25.65 & 1.14 & 21.55 & 36.8 \\
\hline $15-30$ & 19.90 & 13.80 & 66.30 & Clayey & 40.5 & 22.01 & 1.15 & 18.45 & 31.8 \\
\hline $30-45$ & 16.59 & 16.92 & 66.49 & Clayey & 37.0 & 20.10 & 1.24 & 16.91 & 31.4 \\
\hline $45-60$ & 17.65 & 15.24 & 67.12 & Clayey & 34.5 & 18.79 & 1.26 & 15.71 & 29.6 \\
\hline & & & & Tota & & & & & 129.6 \\
\hline
\end{tabular}

F.C = field cap city, PWP Permanent wilting point

\section{Experimental design and treatments}

The experimental treatments were arranged in a split plot design with four replicates. The main- plots represented planting methods; furrows and beds, while the sub-plots were assigned to irrigation scheduling, i.e., $I_{1}$ (1.2), $\mathrm{I}_{2}(1.0)$ and $\mathrm{I}_{3}(0.8)$ of cumulated pan evaporation (CPE). Plot area was 52.5 $\mathrm{m}^{2}$ including 10 rows $7.5 \mathrm{~m}$ long and $70 \mathrm{~cm}$ apart and planting on one side ridge for furrow planting method while it was 5 rows $7.5 \mathrm{~m}$ long, with $140 \mathrm{~cm}$ apart and planting on two sides of ridges for bed planting. All treatments had 7 plants $/ \mathrm{m}^{2}$. The main difference between bed and furrow irrigation systems is the furrow spacing. A furrow spacing figure which is larger than the top width of a furrow implies a bed between two furrows. A bed is created in order to cultivate two rows of sugar beet (i.e. on the left and right side of the bed). Plots were isolated by ditches of $1.5 \mathrm{~m}$ in width to avoid lateral movement of water.

Seeds of sugar beet (Beta Vulgaris L.) were seeded in hills $20 \mathrm{~cm}$ in between at November $3^{\text {rd }}, 5^{\text {th }}$ in two successive seasons 2009/2010 and 2010/2011. Harvesting was done after 190 days .All agricultural practices were done as recommended by the Egyptian Ministry of Agricultural and Land Reclamation, except the two factors of study, i.e., planting methods and irrigation scheduling. The irrigation treatments were imposed after the crop foliage nearly cover the ground as recommended by (Jensen and Middleton, 1965), Eid et al. 1982) and Ibrahim et al., 2002).

Scheduling of the irrigation:

In the present study, the daily evaporation records from class A pan type, was used. The concept of scheduling is that the available soil water (AW) theoretically equals certain ratio of the CPE,(Jensen and Middleton, 1965) and (Eid et al., 1982). The irrigation scheduling by this method needs the determination of the usable soil moisture for each treatment, and the equivalent amount of the CPE that can occur while the amount of the usable moisture is being used. The usable CPE must be determined from meteorological data. This could be expressed by the following equation:

$\mathrm{CPE}=\mathrm{A} . \mathrm{W} \times \mathrm{MAD} / \mathrm{K}_{\mathrm{P}}$

Where:

$\mathrm{CPE}=$ cumulative pan evaporation .

$K_{P}=$ Empirical pan factor (1.2, 1.0 and 0.8 of CPE, respectively, for $I_{1}, I_{2}$ and $I_{3}$ treatments).

AW = Available water $(\mathrm{mm})$ of the soil for the effective root zone depth. $M A D=$ Maximum Allowable Depletion by setting lower limit 50\%. 
The usable soil moisture in the soil depth from which the crop extracts appreciable amount of water could be determined by knowing the AW and the maximum allowable depletion (MAD), (James, 1988). Soil AW for the 60 $\mathrm{cm}$ depth was $129.6 \mathrm{~mm}$, multiply this result by $50 \%$ (MAD for sugar beet) to get $64.8 \mathrm{~mm}$ which is the usable moisture at every irrigation. Divide the usable moisture value $(64.8 \mathrm{~mm})$ by the studied empirical factors $(1.2,1.0$ and 0.8 ) to get the usable CPE for the experimental treatments $I_{1}, l_{2}$ and $I_{3}$ respectively, which after its accumulation can determine the time of the next irrigation. Values of the usable CPE for each treatment are reported in Table (3). They are $54.0,64.8$ and $81.0 \mathrm{~mm}$ for treatments of $I_{1}, I_{2}$ and $I_{3}$ respectively.

Table (3): CPE values for each studied treatment.

\begin{tabular}{|c|c|}
\hline \multicolumn{1}{|c|}{ Treatments } & CPE, $\mathbf{~ m m}$ \\
\hline$l_{1}(1.2 \mathrm{CPE})$ & 81.0 \\
\hline $\mathrm{l}_{2}(1.0 \mathrm{CPE})$ & 64.8 \\
\hline $\mathrm{l}_{3}(0.8 \mathrm{CPE})$ & 54.0 \\
\hline
\end{tabular}

\section{Irrigation management:}

The irrigation in the respective treatments were applied when CPE reached approximately 54.0, 64.8 and $81.0 \mathrm{~mm}$, respectively, for $I_{1}, I_{2}$ and $I_{3}$ treatments. The irrigation water was conveyed to the experimental field through an open channel using a centrifugal pump. The water in the channel was controlled to maintain a constant head by means of fixed bar.

The irrigation water was applied to the experimental plots until reaching the end of the plot length. This was measured and delivered by a constant rectangular weir with steel gates for each plot. The rate of discharge was $0.01654 \mathrm{~m}^{3} / \mathrm{sec}$ at effective head of $10 \mathrm{~cm}$ The of water for each plot of the studied treatments was calculated by the equation;

$\mathrm{Q}=\mathrm{q} \times \mathrm{t}$.

Where :

$Q$ is the volume of water delivered to the plot $\left(\mathrm{m}^{3}\right)$,

$q$ is the discharge of the weir $\left(\mathrm{m}^{3} / \mathrm{min}\right)$ and

$t$ is the time of irrigation (min).

\section{Water applied (Wa):}

Water applied was computed as follows:

$$
\mathrm{Wa}=\mathrm{IW}+\mathrm{Re}
$$

Where:

IW = the amount of water delivered by irrigation to the experimental plots.

$\mathrm{Re}=$ Effective rainfall.

\section{Consumptive use (CU):}

Water consumptive use was determined as soil moisture depletion (SMD) using the following equation, (Hansen et al., 1980).

$\mathrm{Cu}=\sum_{i=1}^{\mathrm{l}=4} \mathrm{D}_{1} \times \mathrm{D}_{\mathrm{b} 1} \times \frac{\mathrm{PW}_{2}-\mathrm{PW}_{1}}{100}$ 
El-Hadidi, E. M. et al.

$\mathrm{CU}=$ Water consumptive use $(\mathrm{cm})$ in the effective root zone $(60 \mathrm{~cm})$.

$\mathrm{D}_{1} \quad=$ Soil layer depth $\left(15 \mathrm{~cm}^{-3}\right.$ each $)$.

$D_{b 1} \quad=$ Soil bulk density, $\left(\mathrm{Mgm}^{-3}\right)$ for the given depth.

$\mathrm{PW}_{1}=$ Soil moisture percentage before irrigation (on mass basis, \%).

$\mathrm{PW}_{2}=$ Soil moisture percentage, 48 hours after irrigation (on mass basis, \%).

$\mathrm{i}=$ Number of soil layers each $(15 \mathrm{~cm})$ depth.

The summation of $\mathrm{Cu}$ between each two irrigations from planting up the harvest give the seasonal crop water consumptive use.

Soil moisture monitoring:

Soil samples were taken at sowing, before each irrigation, 2 days after Irrigation or rainfall, 7-10 days intervals between irrigation and at the time of harvesting, from four layers $(15 \mathrm{~cm}$ each) for each treatment. At each sampling date, duplicate soil samples were taken and were immediately packed in tightly closed cans and transported to the laboratory, then weighed, dried in electrical furnace at $105 \mathrm{C}^{\circ}$ for 24 hours, then weighed again and their moisture content were calculated on dry weight basis (PW).

\section{Crop parameters:}

At harvesting (190 days from sowing) a random sample of ten plants were chosen from each plot to determine some plant parameters of sugar beet growth (root diameter and root length), as well as root weight $(\mathrm{kg})$. Also, some characters of the sugar beet roots quality have been measured and calculated such as sucrose $\%$ and the purity percentage.

Yield (ton/fed):

The yield of the two central furrow or beds were harvested, weighed and computed as:

a- Root yield (ton/fed)

b- Sugar yield (ton/fed) which was computed by multiplying root yield with sucrose percentage. Sucrose percentage was estimated at Delta Sugar Company Limited, Kafr El-Sheikh.

Water productivity (WP) and productivity of the irrigation water (PIW):

It was calculated according to (Ali et al., (2007), using the following equations;

$$
\mathrm{WP}=\mathrm{Y} / \mathrm{Cu}
$$

$$
\mathrm{PIW}=\mathrm{Y} / \mathrm{I}
$$

Where:

WP and PIW $\left(\mathrm{kg} / \mathrm{m}^{3}\right), \mathrm{Y}$ is the yield $(\mathrm{kg} / \mathrm{fed})$, Cu total water consumption of the growing season $\left(\mathrm{m}^{3} / \mathrm{fed}\right.$.) and $\mathrm{I}$ is the irrigation water applied $\left(\mathrm{m}^{3} / \mathrm{fed}\right)$.

Statistical analysis:

The obtained data were statistically analyzed by analysis of variance. according to (Gomez and Gomez, 1984) .Means of the treatment were compared by the least significant difference (LSD) at $5 \%$ level of significance which developed by (Waller and Duncan, 1979). 


\section{RESULTS AND DISCUSSION}

\section{Seasonal Water applied (Wa):}

The seasonal water applied (Wa) of sugar beet consists of two items. These are irrigation (IW) and rainfall (R). The total amount of the effective rain fall was $3.78 \mathrm{~cm}$ and $12.6 \mathrm{~cm}$ for the first and second season, respectively. As reported in Table (4), watering at 1.2 of CPE $\left(\mathrm{I}_{1}\right)$ had the highest amount of irrigation water, due to frequent irrigation, followed by watering at 1.0 CPE $\left(\mathrm{I}_{2}\right)$ and $0.8 \mathrm{CPE}\left(\mathrm{I}_{3}\right)$. Amounts of irrigation water at 1.2 , 1.0 and 0.8 CPE were distributed on 10, 8 and 6 irrigation events including the seedling irrigation. The overall average of the amount of water applied, for the two growing seasons, are $68.2 \mathrm{~cm}\left(2864 \mathrm{~m}^{3} / \mathrm{fed}\right.$.), $60.8 \mathrm{~cm}\left(2554 \mathrm{~m}^{3} / \mathrm{fed}\right)$ and $57.5 \mathrm{~cm}\left(2417 \mathrm{~m}^{3} / \mathrm{fed}\right)$. This means that treatments of 0.8 and $1.0 \mathrm{CPE}$ had less amount of irrigation water applied compared to the treatment of 1.2 CPE by about $447 \mathrm{~m}^{3} / \mathrm{fed} .(15.6 \%)$ and $310 \mathrm{~m}^{3} / \mathrm{fed}(10.8 \%)$, respectively.

In both seasons, the bed planting method received the minimum amount of irrigation water compared to the furrow planting method. The overall average, for the two seasons, of the amount of water applied was 51.1 $\mathrm{cm}\left(2146 \mathrm{~m}^{3} / \mathrm{fed}\right)$ and $68.8 \mathrm{~cm}\left(2889 \mathrm{~m}^{3} / \mathrm{fed}\right)$, respectively for bed and furrow planting methods. This indicate that bed planting method saved water by about $743 \mathrm{~m}^{3} / \mathrm{fed}(25.7 \%)$ compared to the furrow planting method. The trend of these results are in agreement with those of obtained for some field and vegetable crops by (Raut et al., 2000), (Anonymous, 2006) and (Meleha et al., 2004).

Table (4): Seasonal irrigation water (IW), rainfall (R) and seasonal water applied (Wa) for sugar beet in the two growing seasons .

\begin{tabular}{|c|c|c|c|c|c|c|c|c|c|}
\hline \multirow{2}{*}{\multicolumn{2}{|c|}{ Treatments }} & \multicolumn{4}{|c|}{ Season $2009 / 2010$} & \multicolumn{4}{|c|}{ Season $2010 / 2011$} \\
\hline & & \multicolumn{2}{|c|}{ IW } & \multirow{2}{*}{$\begin{array}{c}R \\
\mathbf{c m}\end{array}$} & \multirow{2}{*}{$\begin{array}{l}\text { Wa } \\
\text { cm }\end{array}$} & \multicolumn{2}{|c|}{ IW } & \multirow{2}{*}{$\begin{array}{c}R \\
\mathrm{~cm}\end{array}$} & \multirow{2}{*}{$\begin{array}{l}\text { Wa } \\
\text { cm }\end{array}$} \\
\hline & & No & $\mathrm{Cm}$ & & & No & $\mathrm{Cm}$ & & \\
\hline \multirow{3}{*}{ Bed } & $I_{1}$ & 10 & 62.0 & & 65.78 & 10 & 50.0 & \multirow{3}{*}{12.6} & 62.60 \\
\hline & $\mathrm{I}_{2}$ & 8 & 46.0 & 3.78 & 58.22 & 8 & 39.72 & & 57.76 \\
\hline & $\mathrm{I}_{3}$ & 6 & 40.0 & & 54.94 & 6 & 35.24 & & 56.38 \\
\hline \multicolumn{2}{|c|}{ Mean } & & 49.33 & & 59.65 & & 41.65 & & 58.91 \\
\hline \multirow{3}{*}{ Furrow } & $\mathrm{I}_{1}$ & 10 & 78.67 & & 71.68 & 10 & 69.70 & \multirow{3}{*}{12.6} & 72.88 \\
\hline & $\mathrm{I}_{2}$ & 8 & 64.70 & 3.78 & 66.61 & 8 & 58.08 & & 69.05 \\
\hline & $I_{3}$ & 6 & 57.49 & & 63.98 & 6 & 46.46 & & 65.94 \\
\hline \multicolumn{2}{|c|}{ Mean } & & 66.95 & 67.29 & 58.08 & 2.29 & 70.62 & \multicolumn{2}{|c|}{7.47} \\
\hline
\end{tabular}

Water consumptive use $(\mathrm{Cu})$ :

Tabulated data in Table (5) revealed that in both seasons, sugar beet consumptive use of irrigation scheduling of $1.2 \mathrm{CPE}\left(\mathrm{I}_{1}\right)$ had the highest values of water consumption followed by irrigation scheduling of $1.0 \mathrm{CPE}\left(\mathrm{I}_{2}\right)$ and $0.8 \mathrm{CPE}\left(\mathrm{I}_{3}\right)$, respectively. The overall mean values of the seasonal $\mathrm{Cu}$ were $60.9,47.2$ and $40.7 \mathrm{~cm}$, respectively for treatment of $I_{1}, I_{2}$ and $I_{3}$. This means that the $\mathrm{Cu}$ resulting from irrigation scheduling of 1.2 CPE is higher 
than that of 1.0 and 0.8 CPE by $22.5 \%$ and $33.2 \%$, respectively. It is worthy to mention that the treatment of $1.2 \mathrm{CPE}$ received frequent irrigation (10 irrigation events) more than that of 1.0 and $0.8 \mathrm{CPE}$ which received 8 and 6 irrigation events, respectively. These results demonstrate that water consumption increased as soil moisture was maintained high by frequent irrigation. The probable explanation of these results is that higher frequent irrigation provide chance for more consumption of water which ultimately resulted in increasing the plant transpiration and evaporation from the soil. It was noticed, in general, that seasonal $\mathrm{Cu}$ in the second season was relatively higher than that of the first season. This could be attributed to the less rainfall in the first season $(37.8 \mathrm{~mm})$ compared to that fallen in the second season $(126.5 \mathrm{~mm})$.

On other hand, in both seasons, values of the $\mathrm{Cu}$ were higher under furrow planting than that under bed planting method. Mean values of $\mathrm{Cu}$ under planting method were 52.5 and $50.4 \mathrm{~cm}$, respectively, for the growing seasons of 2009/10 and 2010/11. The corresponding values for the same two seasons under bed planting method were 49.3 and $46.0 \mathrm{~cm}$, respectively. This means that the $\mathrm{Cu}$ values under bed planting were relatively less than that of the furrow planting by about $6.1 \%$ and $8.7 \%$ with an average of $7.4 \%$. This finding is in the same direction with that obtained previously for sugar beet consumptive use by (Eid et al., 1982)

Table (5): Water consumptive use during the two growing seasons of sugar beet crop.

\begin{tabular}{|c|c|c|c|c|c|c|c|c|c|}
\hline \multirow{2}{*}{\multicolumn{2}{|c|}{ Treatment }} & \multicolumn{3}{|c|}{ Season $2009 / 2010$} & \multicolumn{3}{|c|}{ Season 2010/2011 } & \multicolumn{2}{|c|}{$\begin{array}{c}\text { Mean of two } \\
\text { seasons }\end{array}$} \\
\hline & & No. of & $\mathrm{cm}$ & & & & & 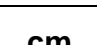 & $M^{3}$ \\
\hline Bed & & $\begin{array}{c}10 \\
8 \\
6 \\
\end{array}$ & $\begin{array}{l}62.0 \\
46.0 \\
40.0 \\
\end{array}$ & & $\begin{array}{c}10 \\
8 \\
6 \\
\end{array}$ & & & & \\
\hline \multicolumn{2}{|l|}{ Mean } & & & & & & & & \\
\hline furrow & $\begin{array}{l}\mathrm{I}_{1}(1.0) \\
\mathrm{I}_{2}(1.0) \\
\mathrm{I}_{3}(0.8\end{array}$ & $\begin{array}{c}10 \\
8 \\
6\end{array}$ & & & $\begin{array}{c}10 \\
8 \\
6\end{array}$ & & & $\begin{array}{l}62.80 \\
50.35 \\
41.35\end{array}$ & $\begin{array}{l}2641.8 \\
2116.8 \\
1738.8\end{array}$ \\
\hline Mean & & & 52.5 & 2207.0 & & 50.4 & 2123.80 & 51.45 & 2185.8 \\
\hline
\end{tabular}

\section{Root length and root diameter $(\mathrm{cm})$}

Mean root length and root diameter as affected by irrigation scheduling and planting method are given in Tables $(6 \& 7)$. The obtained results showed that in both seasons, the longest roots and the smallest diameter of sugar beet were obtained under the treatment of $0.8 \mathrm{CPE}\left(\mathrm{I}_{3}\right)$ while the shortest and the greatest ones were recorded under treatment of 1.2 CPE $\left(I_{1}\right)$. Values of root length were $40.21,37.35$ and $34.31 \mathrm{~cm}$, as an average of the two seasons, for treatments of $l_{3}, l_{2}$ and $l_{1}$, respectively. The corresponding values of root diameter, for the same treatments, were 14.3, 16.33 and $16.40 \mathrm{~cm}$. This means that irrigation scheduling at $0.8 \mathrm{CPE}$ increased the root length by about $7.6 \%$ and $17.2 \%$ compared to that of 1.0 and $1.2 \mathrm{CPE}$, respectively, and decreased the root diameter by about $12.3 \%$ 
and $12.8 \%$ compared to irrigation scheduling at 1.0 and $1.2 \mathrm{CPE}$. This could be explained on the bases of the long irrigation period and less amount of water applied induced from the little number of watering under treatment of $I_{3}$ compared to that of $I_{1}$, (treatments of $I_{3}$ and $I_{1}$, respectively, had 6 and 10 watering during the growing season). These results are similar to those obtained by Ibrahim et al., (2002) found that root grow longer under moisture stress. Also, Emara, (1990) mentioned that the great root length was obtained by irrigation every 28 days, while the lowest root length was obtained by irrigation every 14 days.

Planting methods, also, had highly significant effect on length and diameter of sugar beet roots. The average values of root length, for the two seasons, were 38.51 and $36.08 \mathrm{~cm}$ for bed and furrow planting, respectively. The corresponding values of the root diameter were 15.88 and $15.47 \mathrm{~cm}$, respectively, for the same two planting methods. This means that bed planting method increased the root length by about $6.7 \%$ and root diameter by about $2.6 \%$ compared to the furrow planting method.

Table (6): Effect of irrigation scheduling and planting methods on root length $(\mathrm{cm})$ of sugar beet during seasons of 2009/2010 and 2010/2011.

\begin{tabular}{|c|c|c|c|c|c|c|c|c|}
\hline \multirow{2}{*}{ Treat. } & \multicolumn{3}{|c|}{ Season $2009 / 2010$} & \multicolumn{3}{|c|}{ Season $2010 / 2011$} & \multicolumn{2}{|c|}{$\begin{array}{c}\text { Mean of } 2 \\
\text { seasons }\end{array}$} \\
\hline & bed & furrow & Mean & bed & furrow & Mean & bed & furrow \\
\hline$I_{1}(1.2)$ & $35.83 \mathrm{c}$ & $33.50 \mathrm{c}$ & $34.67 \quad c$ & $34.83 \mathrm{a}$ & $33.07 \mathrm{~b}$ & 33.95 & 35.33 & 33.29 \\
\hline$I_{2}(1.0)$ & $38.87 \mathrm{~b}$ & $37.23 \quad b$ & 38.05 & $39.16 \mathrm{a}$ & $34.16 \mathrm{a}$ & 36.66 & 39.01 & 35.70 \\
\hline$I_{3}(0.8)$ & $41.07 \mathrm{a}$ & $40.10 \quad \mathrm{a}$ & 40.58 & $41.30 \mathrm{a}$ & $38.40 \mathrm{a}$ & 39.85 & 41.18 & 39.25 \\
\hline Mean & 38.59 & 36.94 & 37.77 & 39.54 & 35.94 & 36.21 & 38.51 & 36.08 \\
\hline \multicolumn{9}{|c|}{ In a column means followed by common letter are not significantly different at $5 \%$ level by DMRT } \\
\hline Comparis & & S.E.D & .S.D ( $5 \%)$ & L.S.D (1 & S.E.D & L.S.D ( $5^{\circ}$ & L.S.D & $1 \%)$ \\
\hline 2-1 mean & each F & 0.76 & 1.76 & 2.55 & 0.963 & 2.2 & 3,2 & \\
\hline
\end{tabular}

Table (7): Effect of irrigation scheduling and planting methods on root diameter (cm) of sugar beet during seasons of 2009/2010 and 2010/2011

\begin{tabular}{|c|c|c|c|c|c|c|c|c|}
\hline \multirow[t]{2}{*}{ Treat. } & \multicolumn{3}{|c|}{ Season $2009 / 2010$} & \multicolumn{3}{|c|}{ Season $2010 / 2011$} & \multicolumn{2}{|c|}{$\begin{array}{c}\text { Mean of } 2 \\
\text { seasons }\end{array}$} \\
\hline & bed & furrow & Mean & bed & furrow & Mean & bed & furrow \\
\hline $\mathrm{l}_{1}(0.8)$ & $17.80 \mathrm{a}$ & $16.16 \quad \mathrm{a}$ & 16.98 & $15.20 \mathrm{~b}$ & $16.50 \mathrm{a}$ & 15.85 & 16.50 & 16.33 \\
\hline$I_{2}(1.0)$ & $15.50 \mathrm{~b}$ & 16.60 & 15.60 & $17.33 \quad \mathrm{a}$ & $15.90 \mathrm{~b}$ & 16.62 & 16.42 & 16.25 \\
\hline$I_{3}(1.2)$ & $14.76 \mathrm{c}$ & $14.53 \quad c$ & 14.64 & $14.70 \mathrm{c}$ & $13.16 \mathrm{c}$ & 13.93 & 14.73 & 13.85 \\
\hline Mean & 16.02 & 15.76 & 15.74 & 15.74 & 15.18 & 15.46 & 15.88 & 15.47 \\
\hline
\end{tabular}

In a column means followed by common letter are not significantly different at $5 \%$ level by

$$
\text { DMRT }
$$

Comparison :

2-1 means at each

$$
\text { S.E.D } \quad \text { L.S.D ( } 5 \%)
$$$$
\text { L.S.D (1\%) }
$$$$
\text { S.E.D L.S.D ( } 5 \% \text { ) }
$$

L.S.D (1\%)

Roots and sugar yield (ton/fed).

Data presented in Tables ( $8 \& 9$ ) showed that sugar beet yield of roots and sugar had influenced significantly by irrigation scheduling and the planting methods. Total roots yield varied between 20.4 and 25.04 ton/fed, and sugar yield varied from 3.14 to 4.34 ton/fed, as an overall average for the 
two seasons. The highest roots and sugar yield were achieved with irrigation scheduling of $0.8 \mathrm{CPE}\left(\mathrm{I}_{3}\right)$ followed by treatment of $\left(\mathrm{I}_{2}\right)$, whereas the least ones were recorded for irrigation scheduling of $1.2 \mathrm{CPE}\left(\mathrm{I}_{1}\right)$. This means that the great irrigation intervals induced from the irrigation scheduling at $0.8 \mathrm{CPE}$, due to the low watering number ( 6 irrigation events only during the growing season), increased roots and sugar yield compared to the treatment of 1.2 CPE which had relatively short irrigation intervals induced from the relative great watering number (10 irrigation events during the growing season). These results indicate that irrigation scheduling at $0.8 \mathrm{CPE}$ increased sugar beet roots yield by about $22.7 \%$ and $9.2 \%$, and yield of sugar by about $9.6 \%$ and $12.2 \%$ compared to irrigation scheduling at 1.2 and 1.0 CPE, respectively.

On other hand, as shown in Tables ( $8 \& 9$ ), the bed planting method had significantly higher roots and sugar yield than the furrow planting, in both seasons. The overall average values obtained of roots and sugar yield for bed planting were 23.56 and 3.95 ton/fed, respectively. The corresponding values for the furrow planting method were 22.03 and 3.52 ton/fed, respectively for roots and sugar yield. This indicate that the bed planting method increased sugar beet roots and sugar yield by about $6.9 \%$ and $12.2 \%$, respectively, compared to the furrow planting one. In addition, the highest yield of both beet roots (25.89 ton/fed) and sugar ( 4.68 ton/fed) were obtained by irrigation scheduling at $0.8 \mathrm{CPE}$ with bed planting method.

Table (8): Effect of planting method and irrigation scheduling on root yield (ton/fed) during the two growing season 2009/2010 and 2010/2011

\begin{tabular}{|c|c|c|c|c|c|c|c|c|}
\hline \multirow[t]{2}{*}{ Treat. } & \multicolumn{3}{|c|}{ Season $2009 / 2010$} & \multicolumn{3}{|c|}{ Season $2010 / 2011$} & \multicolumn{2}{|c|}{ Mean of 2 seasons } \\
\hline & bed & furrow & Mean & bed & furrow & Mean & bed & furrow \\
\hline$l_{1}(1.2)$ & $22.630 \mathrm{c}$ & $19.260 \mathrm{c}$ & $20.945 \mathrm{c}$ & $20.73 \mathrm{~b}$ & $19.06 \mathrm{~b}$ & $19.90 \mathrm{c}$ & 21.68 & 19.133 \\
\hline$I_{2}(1.0)$ & $24.814 b$ & $23.043 \mathrm{~b}$ & $23.928 \mathrm{~b}$ & $23.20 \mathrm{~b}$ & $22.78 \mathrm{a}$ & $21.98 \mathrm{~b}$ & 23.12 & 22.780 \\
\hline$I_{3}(0.8)$ & $26.526 \mathrm{a}$ & $24.880 \mathrm{a}$ & $25.703 \mathrm{a}$ & $25.27 \mathrm{a}$ & $23.50 \mathrm{a}$ & $24.38 \mathrm{a}$ & & 90 \\
\hline Mean & 24.650 & 22.394 & & 22.25 & 21.92 & & 23.56 & 22.030 \\
\hline
\end{tabular}

In a column means followed by common letter are not significantly different at $5 \%$ level by DMRT

$\begin{array}{lcccccc}\text { Comparison : } & \text { S.E.D } & \text { L.S.D (5\%) } & \text { L.S.D (1\%) } & \text { S.E.D } & \text { L.S.D ( 5\%) } & \text { L.S.D (1\%) } \\ \text { 2-1 means at each F } & 0.579 & 1.33 & 1.94 & 0.466 & 1.075 & 1.564\end{array}$

Table (9): Effect of planting method and irrigation scheduling on sugar yield (ton/fed) during the two growing season 2009/2010 and 2010/2011

\begin{tabular}{|l|c|c|c|c|c|c|c|c|}
\hline \multirow{2}{*}{ Treat. } & \multicolumn{3}{|c|}{ Season 2009/2010 } & \multicolumn{3}{c|}{ Season 2010/2011 } & \multicolumn{2}{c|}{$\begin{array}{c}\text { Mean of 2 } \\
\text { seasons }\end{array}$} \\
\cline { 2 - 10 } & bed & furrow & Mean & bed & furrow & Mean & bed & furrow \\
\hline$I_{1}(1.2)$ & $3.21 \mathrm{~b}$ & $2.77 \mathrm{c}$ & $2.99 \mathrm{c}$ & $3.70 \mathrm{~b}$ & $2.90 \mathrm{c}$ & 3.30 & 3.46 & 2.83 \\
\hline $\mathrm{I}_{2}(1.0)$ & $3.66 \mathrm{~b}$ & $3.78 \mathrm{~b}$ & $3.72 \mathrm{~b}$ & $4.24 \mathrm{a}$ & $3.76 \mathrm{~b}$ & 4.00 & 3.95 & 3.77 \\
\hline $\mathrm{I}_{3}(0.8)$ & $4.5 \mathrm{a}$ & $3.80 \mathrm{~b}$ & $4.15 \mathrm{a}$ & $4.85 \mathrm{a}$ & $4.18 \mathrm{a}$ & 4.52 & 4.68 & 3.99 \\
\hline Mean & 3.64 & 3.45 & 3.54 & 4.25 & 3.60 & 3.93 & 3.95 & 3.52 \\
\hline
\end{tabular}

In a column means followed by common letter are not significantly different at $5 \%$ level by DMRT

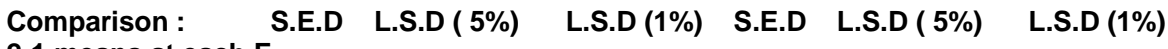

2-1 means at each $F$ 
The lowest yield was obtained by irrigation scheduling at 1.2 CPE with furrow planting method. Therefore, irrigation scheduling at 0.8 CPE with planting in beds method could be considered as an effective method for sugar beet to maximize yield and yield quality in north Nile delta region. These results are supported by those published by several authors concerning the irrigation management for sugar beet yield, Ibrahim et al.,(1995), Emara et al.,(2000) and Eid and Ibrahim (2010).

Productivity of irrigation water (PIW):

As shown in Fig (1) and (2), decreasing the irrigation scheduling from 1.2 to $0.8 \mathrm{CPE}$ increased PIW of both root and sugar yield. The highest average values of PIW 11.09 and $2.8 \mathrm{~kg} / \mathrm{m}^{3}$ for root and sugar yield, respectively, were obtained under treatment irrigation scheduling of $0.8 \mathrm{CPE}$ $\left(I_{3}\right)$, while the lowest ones 6.32 and $0.96 \mathrm{~kg} / \mathrm{m}^{3}$, respectively were obtained under irrigation scheduling of 1.2 CPE $\left(\mathrm{I}_{1}\right)$. These results indicate that irrigation at 0.8 of CPE $\left(I_{3}\right)$ increased the PIW of root and sugar yield by about $43 \%$ and $65 \%$, respectively, compared to irrigation at $1.2 \mathrm{CPE}\left(\mathrm{I}_{1}\right)$. This means that the effect of irrigation scheduling was more pronounced on yield of sugar than on the roots of beet. The higher values of PIW of $\left(\mathrm{I}_{3}\right)$ than that of $\left(\mathrm{I}_{1}\right)$ is obviously due to the less amount of the applied water, (Table 4), and to the higher yield, (Tables 8\&9), of treatment $\left(I_{3}\right)$ than that of $\left(I_{1}\right)$. These findings are in harmony with those obtained by Ibrahim and Emara (2010), Emara et al., (2000), and Eid and Ibrahim (2010) who reported that an adverse effect was found between amount of Wa and PIW for both root and sugar yield.

Concerning the effect of planting method on the PIW, as shown in Fig. (1) planting in beds increased PIW values of root and sugar yield compared to planting in furrow method. This is due to the increase of roots and sugar yield with the planting in beds method.

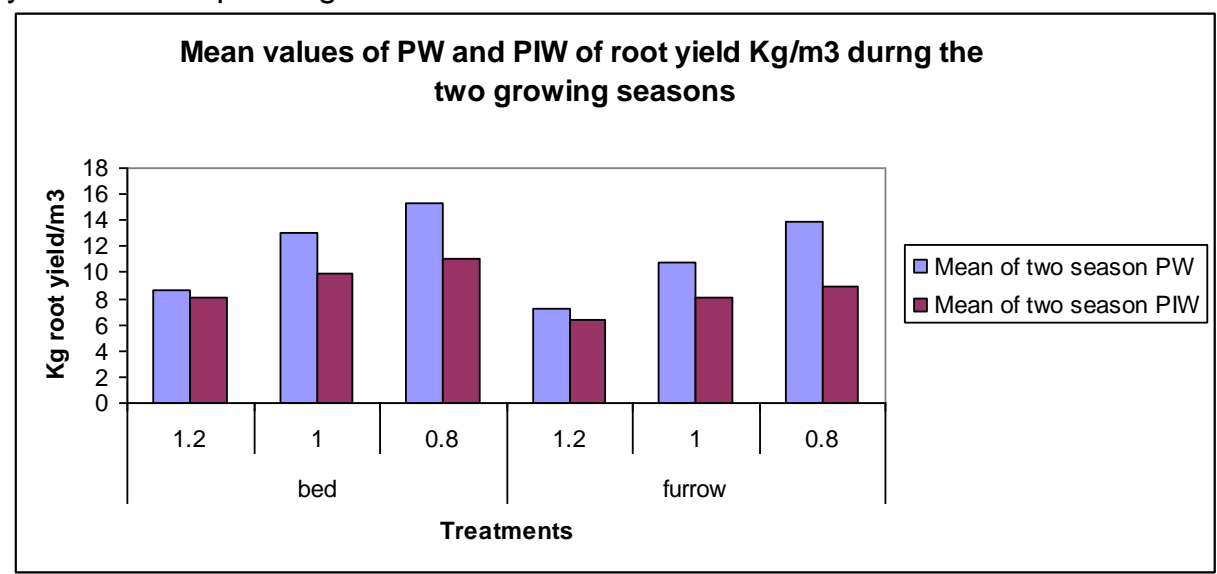

Fig. (1): Mean values of water productivity $\mathrm{Kg} / \mathrm{m}^{3}$ (WP) and Productivity of irrigation water $\mathrm{Kg} / \mathrm{m}^{3}$ (PIW) of root yield in 2009/2010 and 2010/2011 growing seasons. 


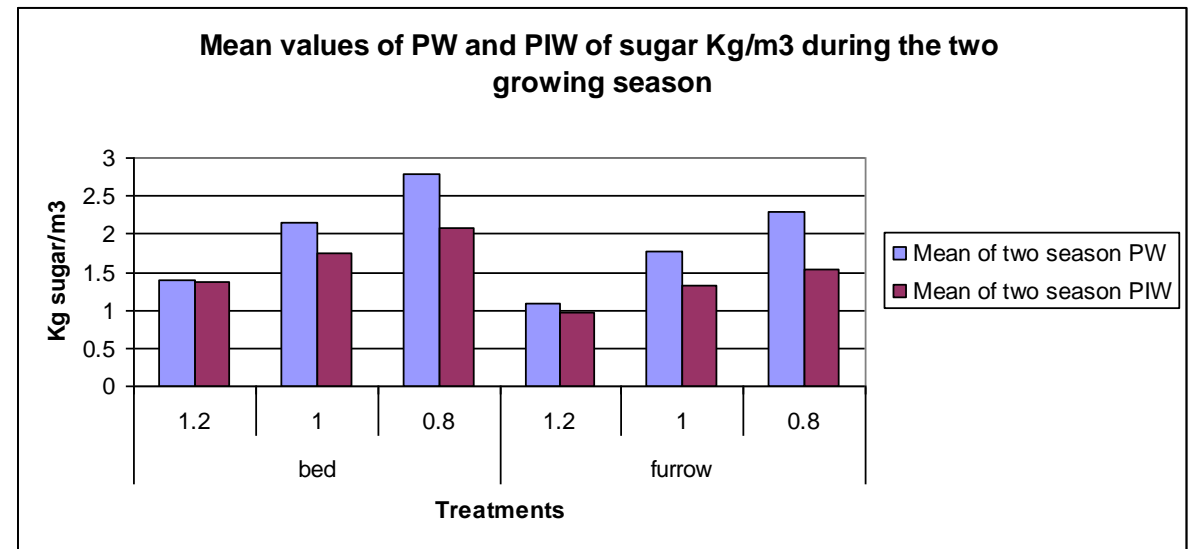

Fig. (2): Mean values of Water productivity $\mathrm{Kg} / \mathrm{m}^{3}$ (WP) and Productivity of irrigation water $\mathrm{Kg} / \mathrm{m}^{3}$ (PIW) of sugar yield in 2009/2010 and 2010/2011growing seasons.

The highest average values of PIW 9.42 and $1.71 \mathrm{~kg} / \mathrm{m}^{3}$ for root and sugar yield ,respectively, were obtained under treatment of bed planting, whereas the lowest ones 7.72 and $1.26 \mathrm{~kg} / \mathrm{m}^{3}$, respectively, were obtained under treatment of furrow planting. This means that bed planting method increased PIW of roots and sugar yield by about $22 \%$ and $35.7 \%$ respectively relative to furrow planting method.

\section{CONCLUSION}

The increasing needs of water for agricultural and non agricultural activities in Egypt require that the available water resource be used efficiently and carefully. Proper irrigation scheduling makes it possible to use water. The obtained results of the present study concluded that irrigation scheduling at 0.8 of CPE with planting in beds is an effective method for sugar beet to maximize yield, yield quality and productivity of the irrigation water under the condition of the studied area, in north Nile delta region. Irrigation scheduling at 0.8 of CPE significantly, increased roots and sugar yield by about $22.7 \%$ and $38.2 \%$, respectively, saved irrigation water by about $24.7 \%$ and $16.2 \%$ compared to irrigation at 1.2 and 1.0 CPE, respectively, and increased the water productivity of root and sugar yield by about $43 \%$ and $65 \%$, respectively, compared to irrigation at $1.2 \mathrm{CPE}$.

Using the bed planting method instead of the furrow planting one, saved water by about $743 \mathrm{~m}^{3} / \mathrm{fed}(25.7 \%)$ with irrigation at 0.8 of CPE and increased roots yield by about $6.9 \%$ and sugar yield by $12.2 \%$ compared to the furrow planting method. There for the bed planting method with irrigation at 0.8 of CPE for sugar beet is recommended to optimize sugar beet yield and the productivity of irrigation water. 


\section{REFERENCES}

Ali, M.H.; M.R. Hoque; A.A. Hassan and A. Khair (2007). Effects of deficit irrigation on yield, water productivity, and economic returns of wheat. Agricultural Water Management 92(3): 151-161.

Anonymous. (2006). Adaptive Research Recommendations. Agri.Deptt., Govt. of the Punjab, Lahore, Pakistan.

Ashraf M., M. M. Saeed and M.N. Asghar (2002)."Evaporation Pan: A Tool for Irrigation Scheduling". Journal of Drainage and Water Management, $6(1): 45-51$.

Ashraf M., M. M. Saeed, M. N. Asgher (2001).Evaluation of Resource Conservation Technologies under Skimmed Groundwater Applications. Journal of Drainage and Water Management. 5(2): 1-10.

Doorenbos, J.; A. H. Kassam; C.L. M. Bentvelson and V. Broncheid (1979). Yield response to water. FAO Irrigation and drainage Paper, No. 33 Rome.

Eid, S. M. and M. M. Ibrahim (2010) Irrigation water salinity and irrigation intervals on growth yield and quality of the sugar beet in saline soil at middle north Nile Delta. J. Soil Sci. and Agric. Engineering, Mansoura Univ., Vol.1 (8): 789 - 800, 2010

Eid, H.M.; M. A. Metwally and F.N. Mahrous (1982) Evaporation pan as an index to consumptive use of water and scheduling irrigation in some field crops. Agric. Res. Review (5),257-279

Emara, S.M. (1990).Effect of irrigation intervals, growth regulars and NK fertilizer on yield and quality of sugar beet. M.Sc. Thesis, Fac. Agric, Mansoura Univ.,Egypt

Emara, T.K.; M.A.M. Ibrahim and M.A. Sherif (2000). Critical beet growth stages in relation to crop water needs in North Nile Delta. Alex. Sci. Exch. Vol. 21, No. 1, pp. 41-53.

FAO. (1996). Irrigation scheduling from theory to practice. Water Reports 8. 384 p. FAO, Rome, Italy.

Gomez, K. A. and A.Gomez (1984). Statistical procedures for agricultural research. 1st ed. John Wiley Sons, New Yourk.

Hansen, V.W.; D.W. Israelsen and D.E. Stringharm (1980). "Irrigation Principle and Practices", 4th ed. Johns Wiley \& Sons., New York.

Ibrahim M.A.; M.M. Ibrahim; S.A. Gaheen and S.M. Ismail (1995). Role of irrigation Management on water parameters and yield of Sugar Beet in Shallow water Table soils of Nlie delta. Water Resources Management in Arid countries, Muscat Sultanate of Oman, March 1995., 98-106.

Ibrahim.M A. M. and T. K. Emara (2010) Water Saving Under Alternative Furrows Surface Irrigation in Clay Soil of North Nile Delta. Fourteenth International Water Technology Conference, IWTC 14 2010, Cairo, Egypt.

Ibrahim.M.;M.R.Khalifa.,M.A.Korim.,F.I.Zein and E.H.Omer (2002 ).Yield and quality of sugar beet crop as affected by mid to late season drought and potassium fertilization at north Nile Delta. Egypt .J. soil science 42 , No . 1 , pp. 87 - 102. 
James, L.G. (1988)." Principal of farm irrigation system design". John Wiley Sons, New York

Jensen, M. C. and J.E. Middleton (1965). Scheduling irrigation from pan evaporation. Circular 386 Washington. Agricultural Experiment Station

Jensen, M.E.(1980). Design and operation of farm irrigation systems. Monograph 3. p. 220-256. American Society of Agricultural Engineering, Michigan, Michigan,USA.

Khalil, F.A. (1996). Scheduling irrigation for faba bean using evaporation pan method. M.Sc. College of Agriculture. Zagazig University, Moshtohor city,Egypt.

Khalil, F.A.F., A.M. Tammam, I.A. Amin, and K.A.Mohamed.( 2006). Scheduling irrigation for some wheat cultivars under Upper Egypt conditions. Mansoura University Journal of Agricultural Sciences.31:561-572

Meleha, M.E.; G.M. Fawzi and U.M. Gawish (2004). Effect of irrig. water management on yield of broad bean and water use efficiency. Egypt. J. Appl. Sci., 19(12B): 787-799.

Raut, V.M., Taware, S.P. \& Varghere, P. (2000). Comparison of different sowing methods in soybean. Journal of Maharashtra Agricultural University 25, 218-219.

Waller, R.A. and D.B.Duncan using . (1979). Symmetric multiple Comparison Problem. Amer. Stat.Assoc. Jour.December, 1485-1503.

Wang, F.H., Liu, S.J., Wang, X.Q., (1999). Eco-physiological effect of wheat bed-planting culture techniques. Shandong Agric. Sci. 4, 4-7 (in Chinese).

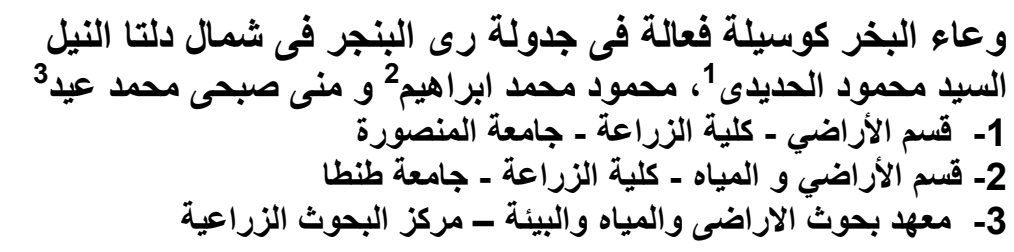

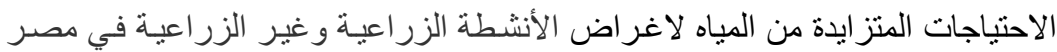

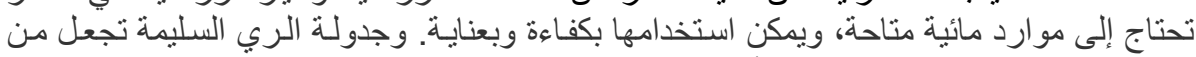

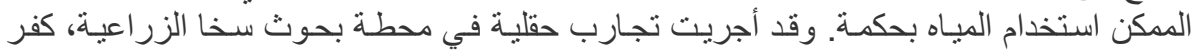

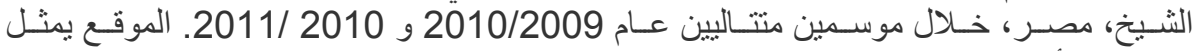

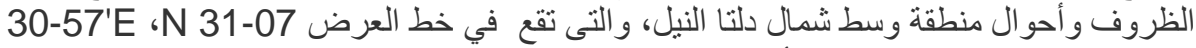

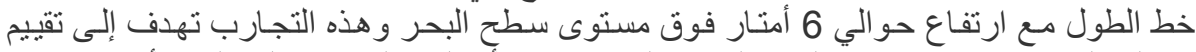

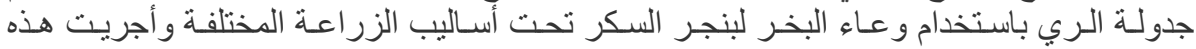

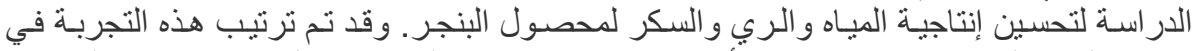

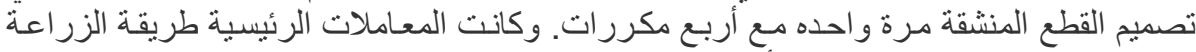

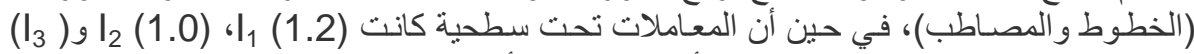

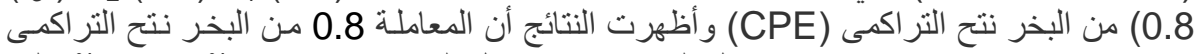

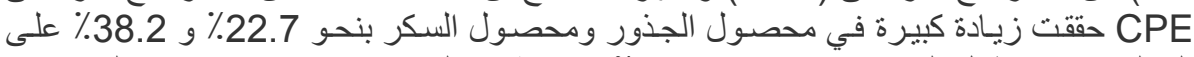
التو الي.وزيادة طول الجذر بنحو 7.6 و 17.2٪، مقارنة مع الري في 1.0 و 1.2 من البخر نتح 


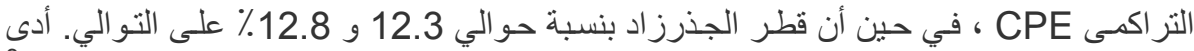

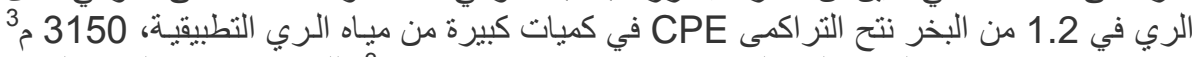

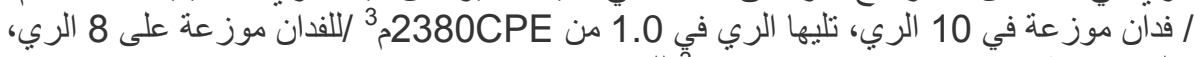

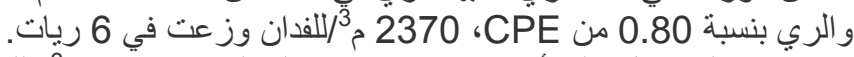

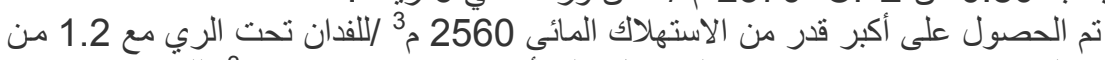

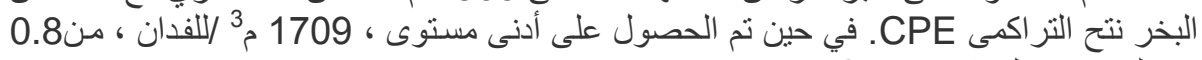

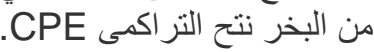

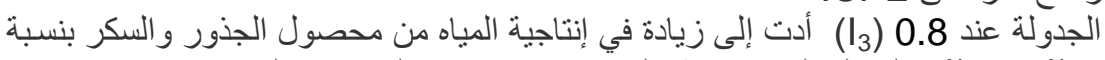

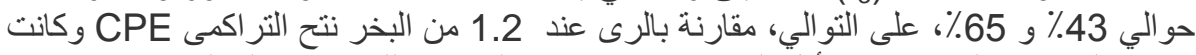

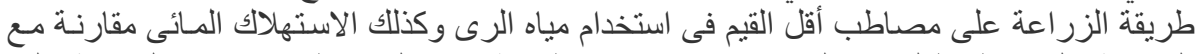

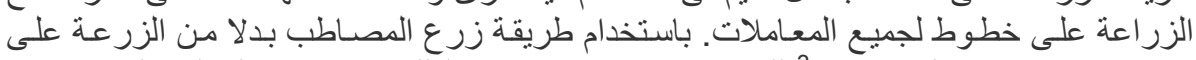

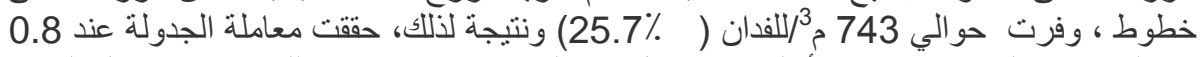

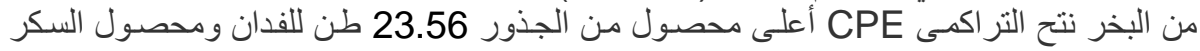

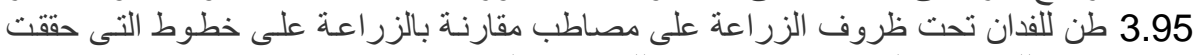

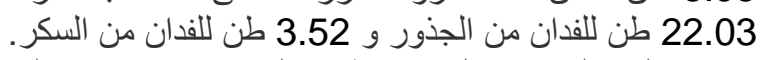

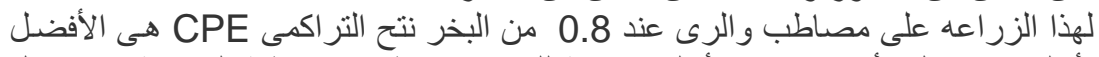

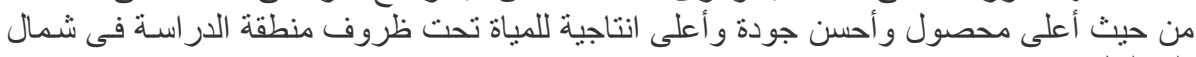

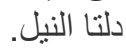

كلية الزراعة - جامعة المنصورة مركز البحوث الزراعية
قام بتحكيم البحث

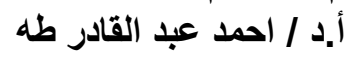

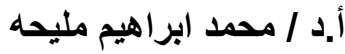

